\title{
https://doi.org/10.46813/2021-131-154 \\ 50 YEARS OF HOT PLASMA DIAGNOSTIC WITH HEAVY ION BEAM PROBING (HIBP) AT THE KHARKOV INSTITUTE OF PHYSICS AND TECHNOLOGY
}

\author{
L.I. Krupnik \\ Institute of Plasma Physics, National Science Center \\ “Kharkov Institute of Physics and Technology”, Kharkiv, Ukraine \\ E-mail: krupnik@ipp.kharkov.ua
}

\begin{abstract}
"The work in Kharkov, Moscow, etc. started by Ludmila Krupnik, progressed largely independently. In fact, the germ of the beam probe concept can be found among the many particle beam based diagnostics ideas she came up within the early years of Soviet fusion research. She and Bob [Hickok] first had a chance to compare concepts and progress when they met at the All-Union Diagnostic Conference in Kharkov in 1977. Unfortunately, until the availability of the Internet, collaboration between the two groups has been limited to occasional discussions at meetings and a couple of short personnel exchanges».

K.A. Connor. IEEE Trans. Plasma Science. 1994, v. 22, № 4, p. 285.
\end{abstract}

An overview describes the evolution of HIBP diagnostics from the origins till today. The progress in the beam technology is presented by examples of HIBPs in tokamaks and stellarators. At the beginning, HIBP provided timeaveraged measurements of plasma potential in single space location, then it evolves to time-resolved measurements of radial distributions and finally it becomes a multi-purpose diagnostics to study the temporal evolution of 2D distributions of potential and turbulence, including the long-range potential correlations with dual HIBP. Highlights in plasma potential profile evolution, a link between potential, density and confinement, geodesic acoustic modes, steady and chirping Alfvén eigenmodes, turbulent particle flux are presented.

PACS: 52.35.Ra, 52.70.Nc, 52.55.Fa, 52.55.Hc

\section{INTRODUCTION}

In the mid-1950s, an intensive development of research aimed at the controlled thermonuclear fusion began. These studies were based on the idea of obtaining hot and dense hydrogen plasmas, detached from the walls of a vacuum chamber by magnetic or electric fields. However, after a fairly short time, it was turned out that obtaining isolated hot and dense plasma is an extremely difficult task. Therefore, direct attempts to obtain energy from controlled fusion had to be replaced by a systematic study of plasma confinement. In this regard, the need arose for development of new methods to study hot plasmas, and the hot plasma diagnostics has been established as a new branch of plasma physics. The methods to study cold plasma of gas-discharge were no longer suitable and new nonperturbing methods were required. These new methods include corpuscular plasma diagnostics based on the analysis of particles, which escaped from or injected into the plasma for its subsequent study. The former refers as passive corpuscular diagnostics, while the latter, as active corpuscular diagnostics.

In 1962, physicists from Kharkiv Institute of Physics and Technology (KIPT) proposed a new method for plasma probing by accelerated beams of neutral atoms. It was used to study the structure of plasma flows (bunches) [1]. At that time the stellarator community did not accept this method due to its technical complexity. Nevertheless, this complexity did not frighten Leningrad scientists to use our method on the toroidal devices "Alpha" and "Tuman" for the first time in 1965-1966.

The use of charged probing particles, ions, opened wider possibilities for the method despite the necessity of accurate determination of the probing beam path. This advance, called HIBP, was proposed by Robert L. Hickok, "the father of heavy ion beam probing" from Rensselaer Institute of Technology, USA.

Kharkiv scientists, who originated the concept of particle beam probing, were able to continue its development only from the early 1970 s that is worldwide recognized, see epigraph. The necessary conditions for the application of the active corpuscular diagnostics, the basic principles and capabilities of HIBP were reviewed in Refs. [2, 3].

Further development of HIBP made it capable to simultaneously measure several key plasma parameters, as well as their fluctuations, with high temporal and spatial resolution. They are: plasma potential $\varphi_{p l}$, density $n_{e}[4,5]$, electron temperature $T_{e}$, and poloidal magnetic field $B_{p o l}$ (or the plasma current density $j_{p l}$ ) [6]. Moreover, the possibility of direct local measurements of plasma potential $\varphi$ is unique.

\section{IMPLEMENTATION OF HIBP ON TOKAMAKS AND STELLARATORS}

In the 1980s, low-to-high confinement mode transition (L-H transition) was discovered at the ASDEX Upgrade tokamak [7]. Theorists explained the L-H transition by spontaneous bifurcation of the radial 
electric field $E_{r}$, reinforces an interest to electric field studies. As it was written in Ref. [8]: "Understanding of the role of electric field in confinement is almost equivalent to the understanding of plasma confinement itself".

At that time, we have analyzed the availabilities of existing fusion devices for the implementation of HIBP. The probing beam trajectory calculations allowed us to determine the location of the probing equipment and its parameters. TM-4 tokamak (Kurchatov Institute, Moscow) and Uragan-2M (KIPT, Kharkiv) were most suitable. The magnetic configuration of tokamak appeared to be more favorable for beam probing and this determined our start. The equipment was developed in KIPT and installed on TM-4 [9]. The first encouraging results were achieved on TM-4 [10] arose the further demand for the diagnostics. The area of HIBP developments was expanded significantly after presentation our results at the international conferences. HIBP researches were performed in tokamaks: TM-4 (Moscow, 1978-1980), T-10 (Moscow, 1990-2018) [1113 ], Tuman-3M (St. Petersburg, 1983 - now) [14], TJ-I (Madrid, 1991-1995) [15, 16] and in stellarators: TJ-II (Madrid, 1996 - now) [17], WEGA (Greifswald, 20042009) [18-21] and Uragan-2M (Kharkiv, 1985 calculations, 2012 - installation) [22]. Main parameters of devices and HIBPs are collected in Table 1. HIBP projects mention for ITER [23, 24], TCV [25], TCABR [26], W7-X [27, 28], spherical tokamaks [29], including MAST [30], Globus-M2 [31] and T-15MD [32] also. Progress in HIBP development was reviewed in the whole issue of IEEE Trans. Plasma Sci. v. 22, № 4 (1994), including paper [33], then in Refs. [34, 35] and finally in the books [36, 37]. We show the general scheme of HIBP for TJ-II stellarator (Fig. 1) by example. HIBP hardware consists of two main parts: an injector of accelerated probing beams and a detecting unit for analyzing secondary ions. Diagnostics has two beam-lines for correcting the primary and secondary ion beams. An operation of HIBP is provided by control and data acquisition systems [38]. Requirements for HIBP hardware are determined by the parameters of each fusion device, on which the experiment is planned. They are the energy and mass of the probing ions, the level of stability of the accelerator parameters, the primary beam current and the temporal and spatial resolution of measurements. A beam injector consists of the ion source, electrostatic accelerator and primary beam-line. A probing beam should has a minimum energy spread in order to maximize sensitivity of measuring the plasma potential, sufficiently large ion mass to pass through the magnetic fields and the current to overcome the beam attenuation in the plasma $\left(I_{b} \geq 100 \mu \mathrm{A}\right)$ [39]. The beam sources should withstand long-term manyhour operation [40]. The detecting unit system consists of an energy analyzer with a detector of the beam toroidal displacement $\zeta_{\mathrm{d}}$ and the secondary ion beam current $I_{t o t}$. Parameters of analyzer are determined during the calibration by gas target at the special testbench [41, 42]. The dedicated hardware and software packages for processing and viewing obtained data was developed $[5,43]$. The special efforts were undertaken to estimate the locality of measurements and the path integral effect. A multi-slit analyzer allows us to directly measure plasma turbulence rotation [44, 45] poloidal component of electric field $E_{p o l}$ and to estimate radial particle flux $[46,47]$ in some radial range. HIBP measurements allowed to clarify the role of sheared flow in turbulence suppression and establishment of transport barriers [48, 49].

Kharkiv HIBPs were installed at the devices worked according to the worldwide fusion program. The main results were obtained on TM-4 [50], T-10 [51], and TJ-II [52-61].

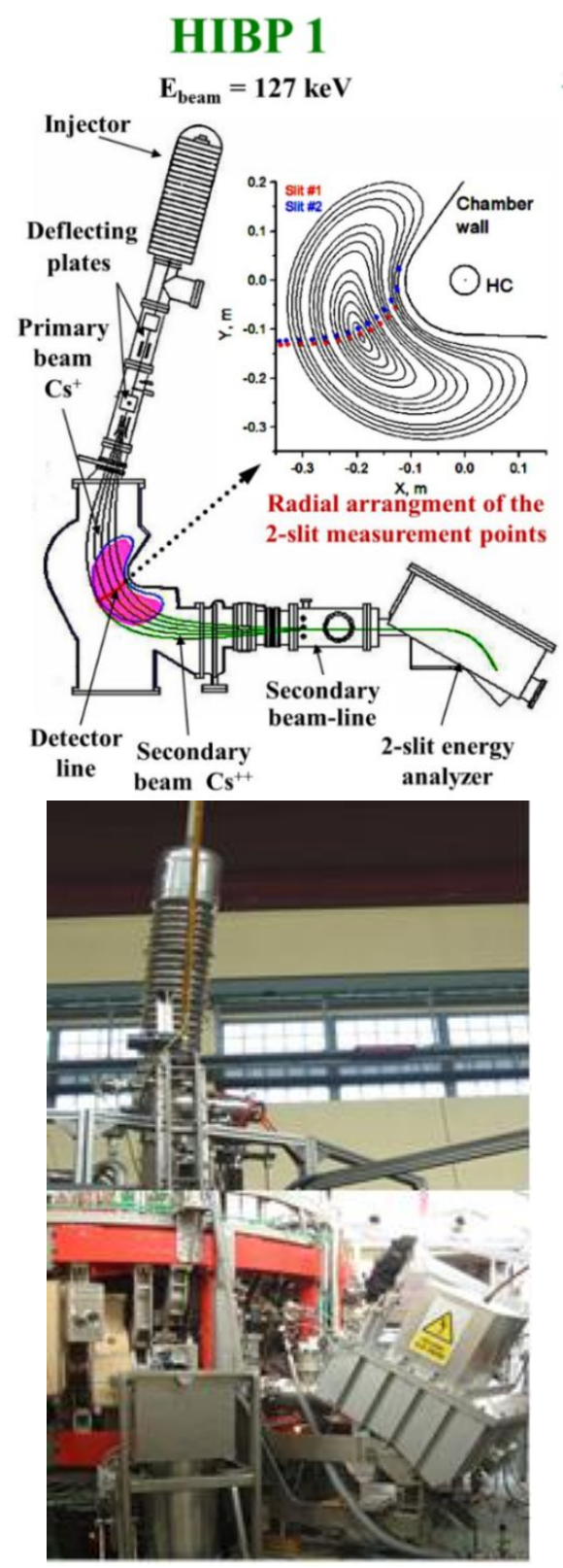

Fig. 1. General scheme of HIBP diagnostics and photo of HIBP I diagnostics on the TJ-II stellarator

\section{MEASUREMENTS OF PLASMA POTENTIAL}

Fig. 2 shows the radial plasma potential profiles and the evolution with plasma density changes for TM-4, $\mathrm{T}-10$, and TJ-II. The ohmic heating was used on TM-4 $(\mathrm{OH})$; on TJ-II ECRH+NBI (electron-cyclotron resonance and neutral beam injection heating); on T-10 $\mathrm{ECRH}+\mathrm{OH}$. 
Table 1

Devices with HIBP and parameters of probing beam

\begin{tabular}{|c|c|c|c|c|c|c|c|}
\hline $\begin{array}{c}\text { Device / } \\
\text { parameter }\end{array}$ & TJ-I & WEGA & TM-4 & TJ-II & $\mathrm{T}-10$ & $\begin{array}{c}\text { Tuman- } \\
3 \mathrm{M}\end{array}$ & $\begin{array}{c}\text { Uragan- } \\
2 \mathrm{M} \\
\end{array}$ \\
\hline$R, \mathrm{~m}$ & 0.54 & 0.72 & 0.53 & 1.5 & 1.5 & 0.53 & 1.7 \\
\hline$a_{\lim ,} \mathrm{m}$ & 0.085 & 0.19 & 0.085 & 0.22 & 0.3 & 0.22 & 0.22 \\
\hline$B_{\mathrm{t}}, \mathrm{T}$ & $1.1 \ldots 1.4$ & 0.5 & $1.2 \ldots 2.0$ & 1.0 & $1.5 \ldots 2.5$ & 1.2 & 0.5 \\
\hline$n_{e}, 10^{19} \mathrm{~m}^{-3}$ & 0.5 & 0.5 & $0.6 \ldots 4.0$ & $0.3 \ldots 6.0$ & $1 \ldots 4$ & $1 \ldots 6$ & 0.2 \\
\hline$P_{\text {ECRH }}, \mathrm{MW}$ & - & - & - & $\leq 0.6$ & $\leq 2.2$ & - & - \\
\hline$P_{\mathrm{NBI}}, \mathrm{MW}$ & - & - & - & $\leq 0.9$ & - & 0.6 & - \\
\hline \multicolumn{8}{|c|}{ HIBP Diagnostics } \\
\hline$E_{\mathrm{b}}, \mathrm{keV}$ & 100 & 60 & 100 & 125 & 300 & 100 & 70 \\
\hline Probing ions & $\mathrm{Cs}^{+}$ & $\mathrm{Na}^{+}$ & $\mathrm{Cs}^{+}$ & $\mathrm{Cs}^{+}$ & $\mathrm{Tl}^{+}$ & $\mathrm{K}^{+}$ & $\mathrm{Cs}^{+}$ \\
\hline $\begin{array}{c}\text { Radial range of } \\
\text { measurement }\end{array}$ & $-1<\rho<1$ & $0.4<\rho<1$ & $0<\rho<1$ & $-1<\rho<1$ & $0.2<\rho<1$ & $0<\rho<1$ & $0<\rho<1$ \\
\hline
\end{tabular}
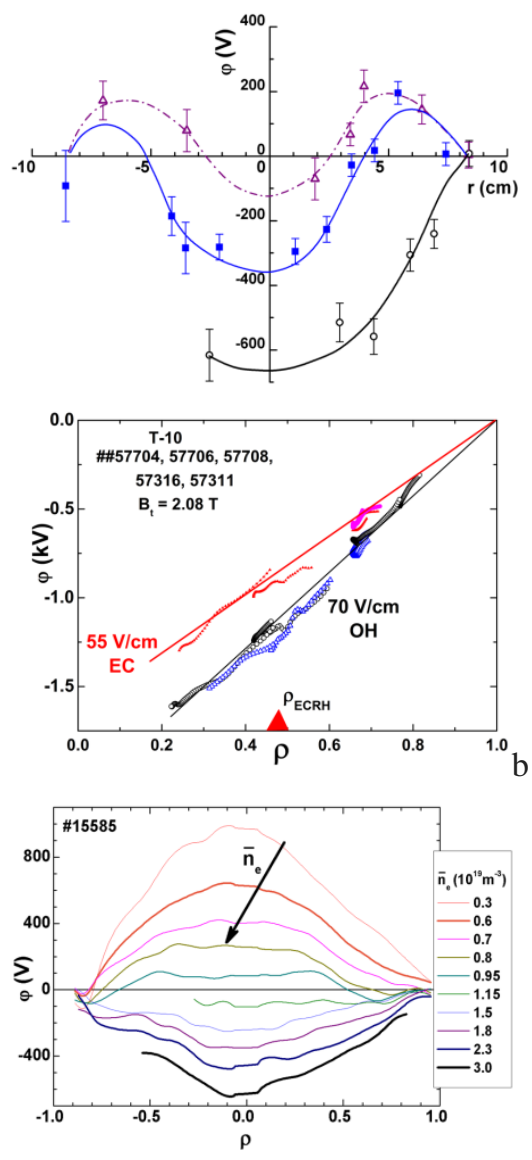

Fig. 2. The radial profiles of plasma potential on TM-4:

$\Delta, \mathbf{m}$, and $\circ$, corresponding to $\bar{n}_{e}=0.6 \cdot 10^{19}, 2 \cdot 10^{19}$, and $4 \cdot 10^{19} \mathrm{~m}^{-3}(a)$;

T-10: ohmic heating (b), ECR heating and current ramp-up: and TJ-II discharge with rising $n_{e}(c)$

The behavior of the plasma potential is similar despite the different methods of plasma creating and heating, as well as magnetic configurations of the devices. An increase on $n_{e}$, and consequently, an increase on the plasma confinement time are accompanied by potential evolution to the negative direction, it may reach hundreds and even thousands of volts. Fig. 3 shows the results of numerous measurements of the plasma potential, performed on T-10 tokamak and TJ-II stellarator. Large circles in Fig. 3 show results of neoclassical simulation of potential [62]. A similar picture is observed: the potential evolved toward more negative values with the density and effective collisionality $v_{\text {eff }}$, however, this dependence saturates, when plasma density reaches a certain threshold value $\bar{n}_{e} \sim(2.5 \ldots 3.5) \cdot 10^{19} \mathrm{~m}^{-3}$, in both devices [63-67].

HIBP measures the potential profiles in the plasma core in experiments with forced L-H transition, when the bias voltage was applied to the special electrode, inserted into the plasma edge on $\mathrm{T}-10$ or to the limiter in TJ-II $[68,69]$.

\section{MEASUREMENTS OF TURBULENCE}

All capabilities of HIBP diagnostics to measure the radial profiles of plasma parameters and their fluctuations were used in the studies of quasicoherent oscillations - zonal flows (ZF) in T-10 [70] and Alfvén eigenmodes (AEs) on TJ-II [71, 72].

\subsection{ZONAL FLOWS IN T-10}

Poloidal ZF are considered as the mechanism of turbulence self-regulation, which affects the radial transport in tokamaks and stellarators. The most striking manifestation of zonal flows is observed in the oscillations of the plasma potential. ZF split into two branches: a low-frequency ZF and high-frequency part, geodesic acoustic modes (GAMs). At present, ZF/GAM is considered as a mechanism influencing the $\mathrm{L}-\mathrm{H}$ transition. Fig. 4 presents the main results of the study of GAM at T-10 [73-75]. GAM was directly observed by an oscillation of the plasma potential in the frequency range of $10 \ldots 30 \mathrm{kHz}$. A low-frequency branch of about $1 \mathrm{kHz}$ apparently also exists at T-10, and this, according to the theory, is indicated by the intermittent character of GAMs, as presented in Fig. 4, where oscillations at $7 \mathrm{kHz}$ are MHD mode $m=2$. GAM, dominating in the plasma potential spectrum, have amplitude up to $100 \mathrm{~V}$, but they are much less visible on density fluctuations (proportional to $I_{t o t}$ ). It looks like a rather narrow isolated peak in potential spectrum. Often GAM has the high-frequency satellite. The local theory predicts that the GAM frequency scales as $f_{G A M}=1 / 2 \pi R \cdot \sqrt{2 T_{e} / m_{i}}$ if $T_{e}$ is taken near the plasma edge. 

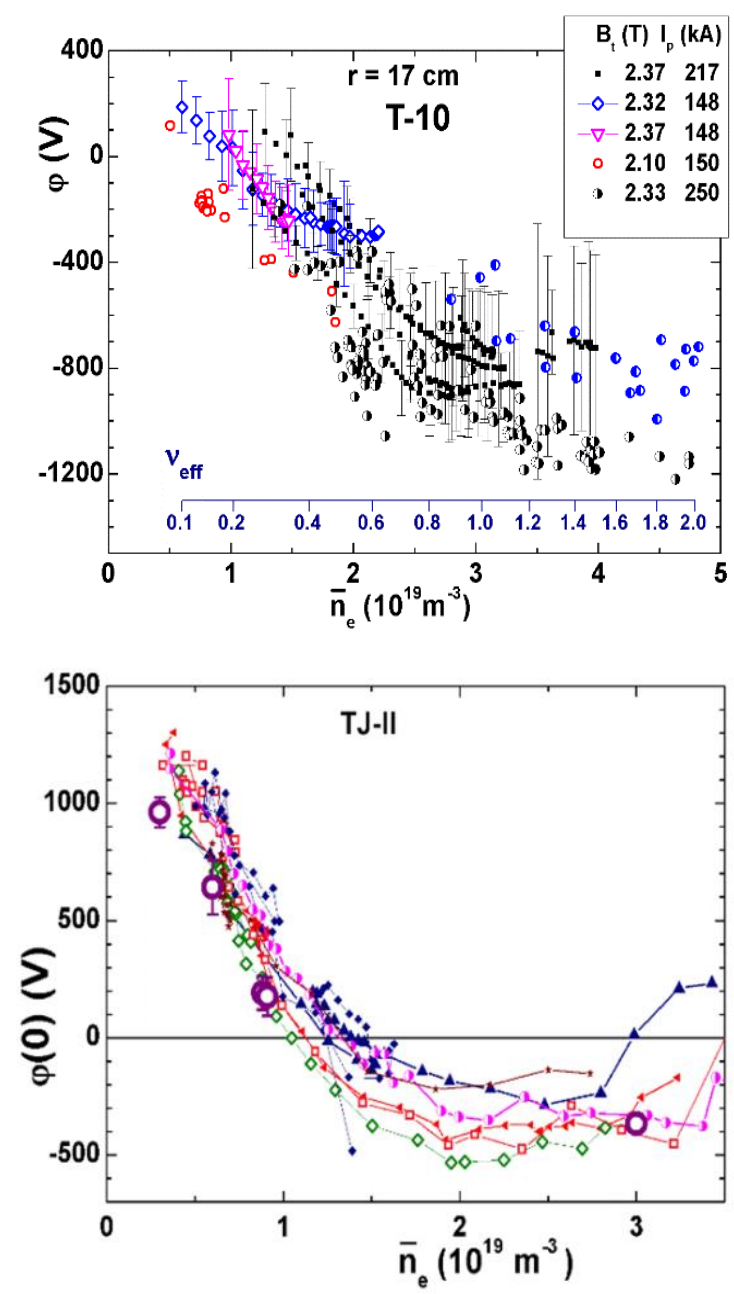

Fig. 3. Results of numerous measurements of the plasma potential in $T-10\left(\overline{n_{e}}=(0.6 \ldots-4.7) \cdot 10^{19} \mathrm{~m}^{-3}\right.$, $\left.I_{p l}=120 \ldots 300 \mathrm{kA}, q_{a}=2.8 \ldots 5\right)$ and TJ-II $\left(\overline{n_{e}}=0.3 \ldots 4.5\right) \cdot 10^{19} \mathrm{~m}^{-3}$, $\left.\downarrow / 2 \pi=1.5 \ldots 1.75, q_{a}=0.57 \ldots 0.67\right)$

\subsection{ALFVÉN EIGENMODES ON TJ-II}

Over the two past decades, much attention in fusion studies has been paid to the issue of AEs, excited by fast particles like NBI or fusion-born alphas. AEs should significantly affect the transport of both fast and the thermal plasma components, according to the theory, since they involve the intertwinement between them. AEs were studied by magnetic probes (MP) located at TJ-II vacuum chamber. This is do not bringing information about AEs spatial structure and characteristics. A new diagnostic was required, capable to observe the AEs in the plasma core from the edge to the very center. It was HIBP, which answers the challenge [76].

Fig. 5 shows the temporal evolution of the spectral power density, PSD (Fourier spectrogram) of $I_{\text {tot }}$ proportional to plasma density fluctuations (a); the plasma potential $\varphi(b)$; and the toroidal beam displacement $\zeta$, proportional to poloidal magnetic field $B_{\mathrm{pol}}$ (c); together with the signal of MP and average density $n_{e}(\mathrm{~d})$. Combined ECR +NBI heating were used in this discharge.
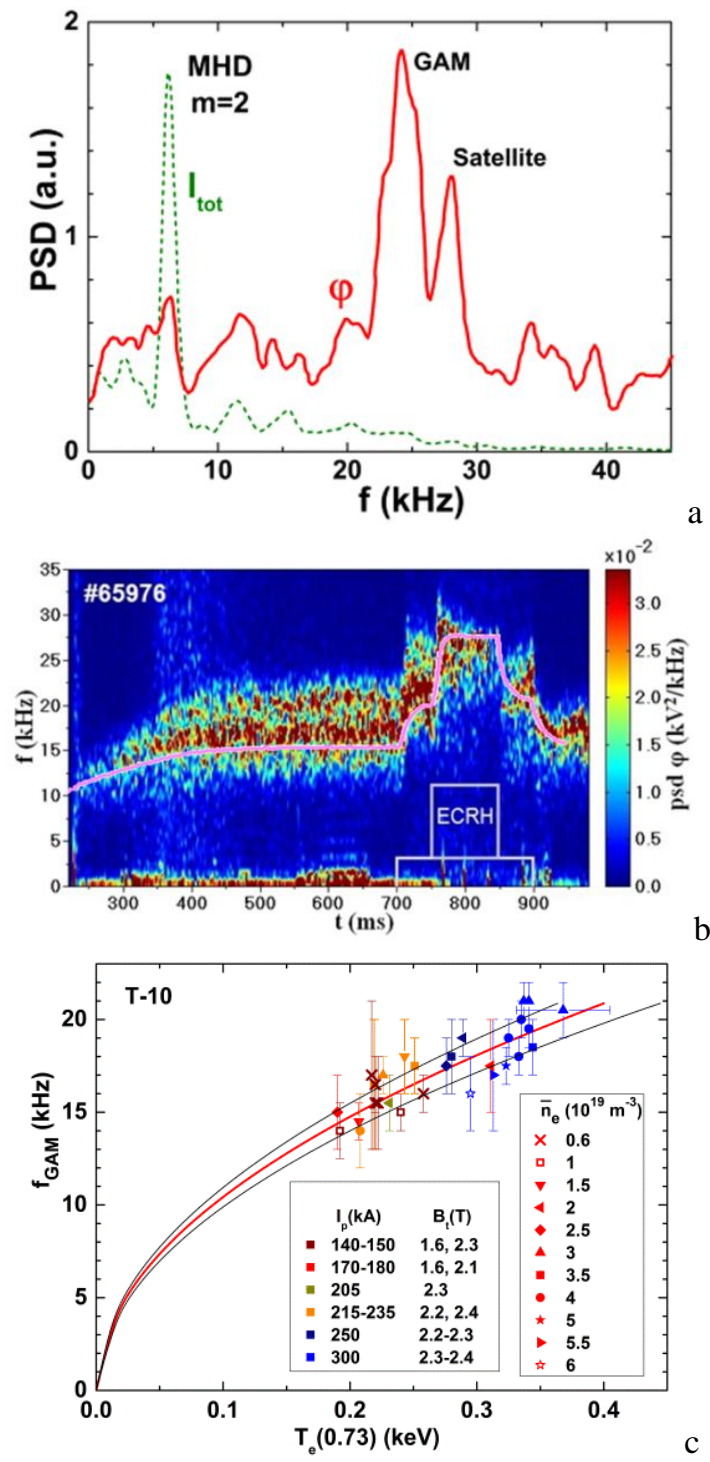

Fig. 4. Typical potential $(\varphi)$ and density $\left(I_{\text {tot }}\right)$ power spectra for GAM frequency range in T-10 ohmic shot (a); spectrogram of the GAM evolution measured atr $=0.24$ min the shot with step-wise ECRH power. The GAM intermittent structure is observed. Solid line is the square root of ECE signal proportional to $\sqrt{T_{e}}$ at $r=0.18 \mathrm{~m}(\mathrm{~b})$; dependence of GAM frequency on the electron temperature at the radius $\rho=0.73$.

Lines are square root dependencies with variation by $10 \%(c)$

We see the presence of $\mathrm{AE}$ in the form of multiple quasi-monochromatic frequency peaks $f_{A E}$ (branches 1-4), which are well pronounced in all measured parameters including the plasma potential, density and magnetic field. $\mathrm{AE}$ is an electromagnetic wave; its electric component was first observed by HIBP.

HIBP with multi-slit detection allows us to study the phase characteristics of each $\mathrm{AE}$ branch and their contribution to the turbulent particle flux. It was found that each AE branch could have its individual value and sign of the flux, determined by cross-phase between $n_{e}$ and $E_{p o l}$ oscillations [77]. 

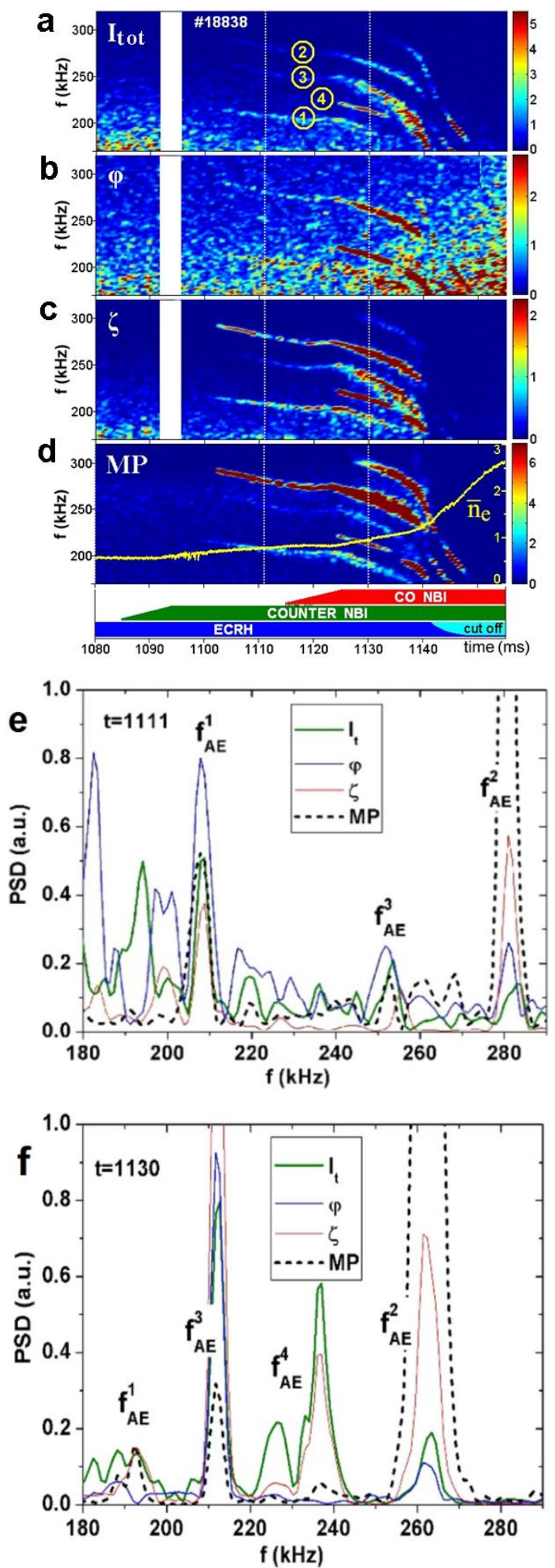

Fig. 5. The temporal evolution of the power spectral density (PSD) or the Fourier spectrogram of AEs, seen on $I_{\text {tot }}$ - proportional to plasma density fluctuations (a); the plasma potential $\varphi(b)$; toroidal beam displacement

$\zeta_{d}$ - proportional to poloidal magnetic field $B_{\text {pol }}(c)$; together with the signal of MP and average density $(d)$; AEs branches with co-NBI (e) and AEs branches with balanced $N B I(f)$

In low-density ECRH / NBI plasmas the AE mode has a pulsed character, having the so-called chirping-up frequency or chirping mode [78]. The chirping mode is clearly pronounced in the magnetic component $B_{p o l}$, Fig. 6 [79]. Radial scan of the measuring point allows us to detect the place of birth for the chirping mode and to monitor its space-frequency evolution [80].
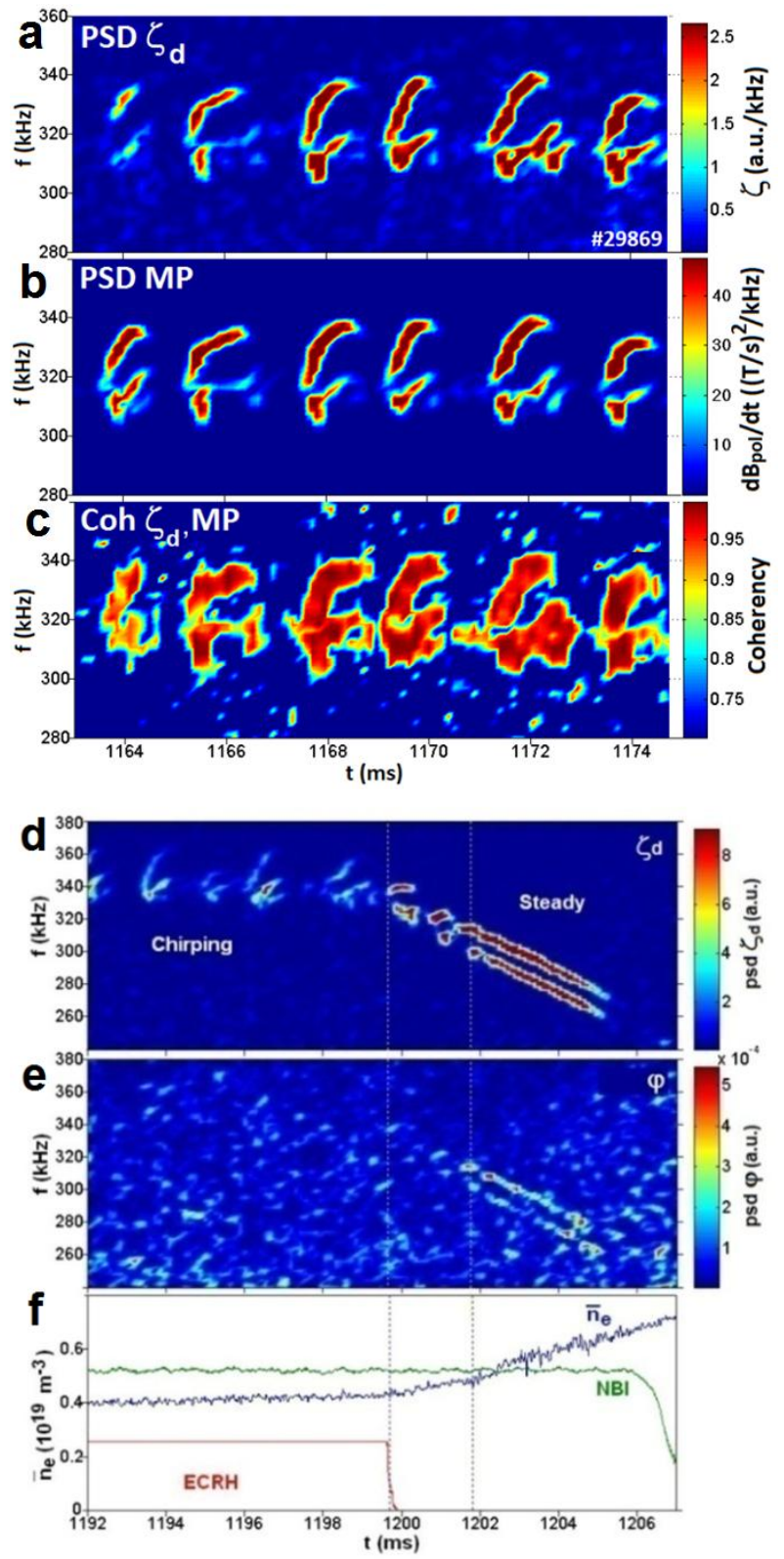

Fig. 6. Chirping Alfvén modes are seen on spectrograms of $\zeta_{d}\left(\right.$ or $\left.B_{p o l}\right)$ and MP with a high coherency $(a, b, c)$; delayed transition from chirping modes, excited in lowdensity plasma with ECRH, to AEs with smooth change of frequency in accordance with Alfvén scaling $f_{A E} \sim n_{e}^{-1 / 2}$ with the density rise due to NBI heating $(d, e, f)$

It was found that transition from steady to chirping $\mathrm{AE}$ is very sensitive to variation of magnetic configuration by small change of currents in helical coils. It allows one to propose this effect in combination with local ECRH for controlling transport of fast particles and mitigation of AE.

It has been established that the contribution of turbulent $\boldsymbol{E} \times \boldsymbol{B}$ particle flux induced by AE can vary from insignificantly small value to the level comparable with broadband $\boldsymbol{E} \times \boldsymbol{B}$ turbulent flux. 


\subsection{MEASUREMENTS OF OTHER TURBULENT MODES}

The new type of quasicoherent modes were discovered on TJ-II using HIBP. These are oscillations excited by fast (supra-thermal) electrons (ST-mode) and resonant oscillations of plasma density $[81,82]$.

A low-frequency tearing-like mode (TLM) was found during NBI heating on TJ-II. This mode is strictly localized in the peripheral region $(0.6 \leq \rho \leq 1.0)$, and it is clearly manifested in the secondary ion current $I_{\text {tot }}$ (plasma density) and in the MP signals. Fig. 7 and Table 2 summarize results of numerous quasicoherent oscillations studies on TJ-II and show the frequency range and radial location for the entire "zoo" of the observed modes [83-86].

Table 2

Results of numerous quasicoherent oscillations studies on TJ-II

\begin{tabular}{|c|c|c|}
\hline Mode type & $\begin{array}{c}\text { Frequency } \\
\text { range, } \mathrm{kHz}\end{array}$ & $\begin{array}{c}\text { Radial } \\
\text { range, }|\rho|\end{array}$ \\
\hline $\begin{array}{c}\text { LRC, } \\
\text { electrostatic }\end{array}$ & $\leq 30$ & $<0.8$ \\
\hline ST, electrostatic & $15 \ldots 25$ & $0.2 \ldots 0.6$ \\
\hline $\begin{array}{c}\text { AE, } \\
\text { electromagnetic }\end{array}$ & $100 \ldots 300$ & $0.4 \ldots 0.8$ \\
\hline TLM, magnetic & $10 \ldots 15$ & $0.6 \ldots 1$ \\
\hline
\end{tabular}

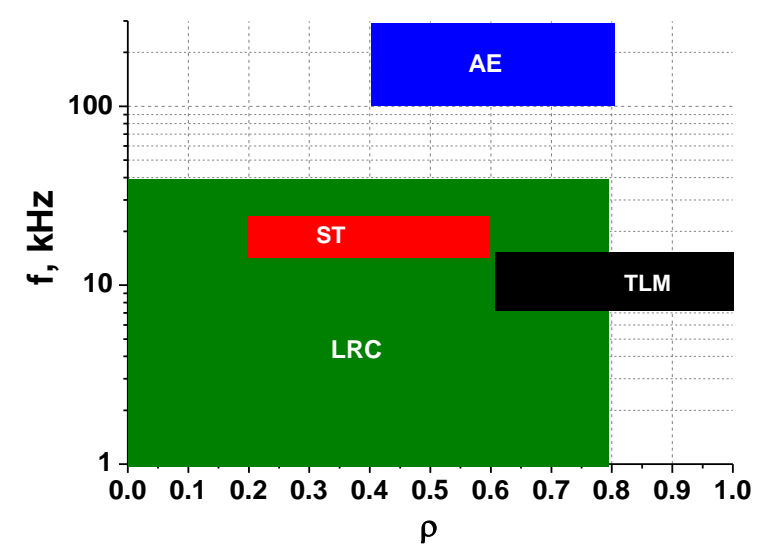

Fig. 7. Types, frequencies and radial localizations of various modes of oscillations observed on TJ-II

\section{DUAL HIBP IN TJ-II}

HIBP-2 second system was installed on TJ-II in 2011 in a section placed $90^{\circ}$ along the torus relatively to HIBP-1, Fig. 8 [87]. Dual HIBP elevated HIBP diagnostics up to a new level and allowed us to measure long-range correlations (LRC) of plasma potential, density and poloidal magnetic field, the toroidal and poloidal structure of plasma turbulence and various types of instabilities in the core and edge plasmas. Currently, dual HIBP is highly demanded and commonly used in all research programs on TJ-II (study of ZF, L-H transitions, ELM characteristics, AEs and MHD activity and pellet injection) [88]. New capabilities of dual HIBP were demonstrated in experiment, in which relaxation of oscillating radial electric field $E_{r}$ after injection of cryogenic pellet was investigated. The waveform of the $E_{r}$ relaxation is consistent with gyrokinetic modeling, which shows that the turbulent transport depends on the collisionless damping of ZF [89].

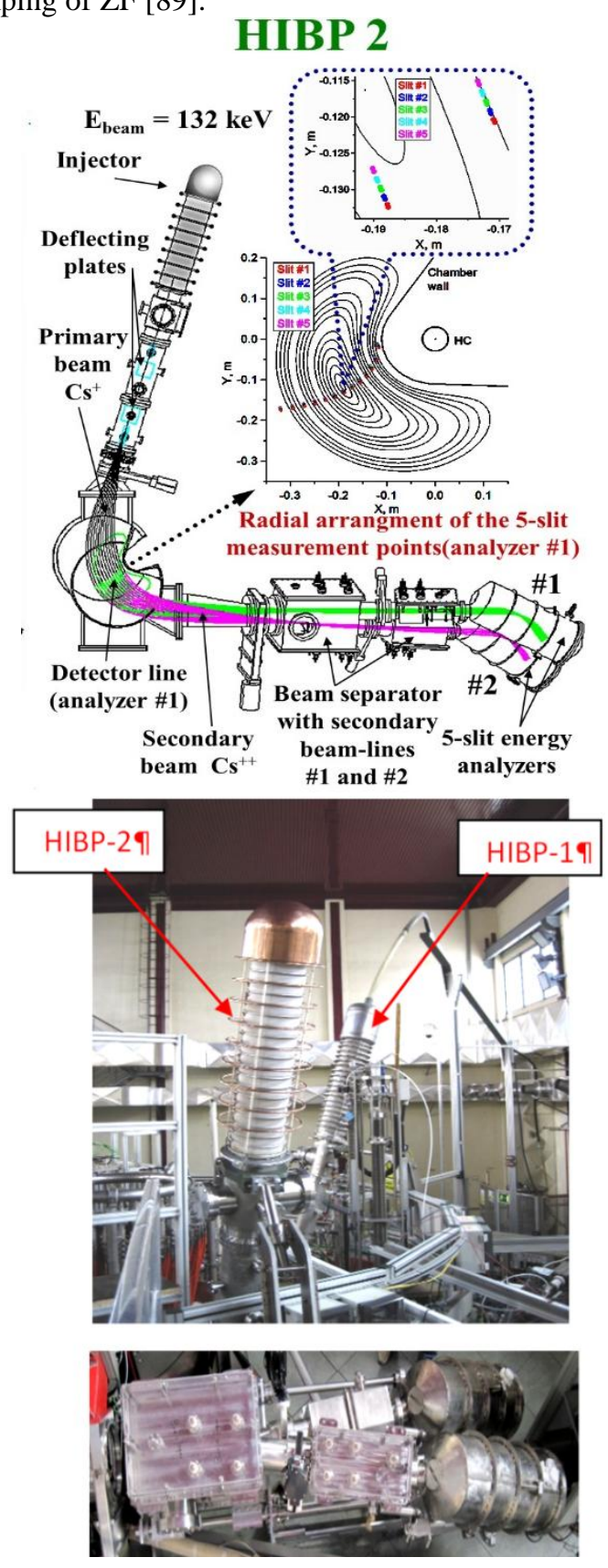

Fig. 8. The scheme of HIBP-2 system and photo of HIBP-1 and HIBP-2 installed on TJ-II in sections shifted by $90^{\circ}$ along the torus relative to each other (up) and 5-slits analyzers (down)

\section{HIBP IN "URAGAN-2M"}

Traveling around the cities and countries, we have always looked forward to the opportunity to operate HIBP diagnostics in the home institute, KIPT. In 2012 this long-awaited moment at last came, and HIBP was installed on "Uragan-2M" stellarator-torsatron in KIPT (Fig. 9) with funding by STCU Grant and with active support of V.I. Tereshin. "Uragan-2M" is the last in a series of machines, for which HIBP was developed, therefore we installed the most advanced version of all equipment, which was developed in collaboration with worldwide colleagues. 

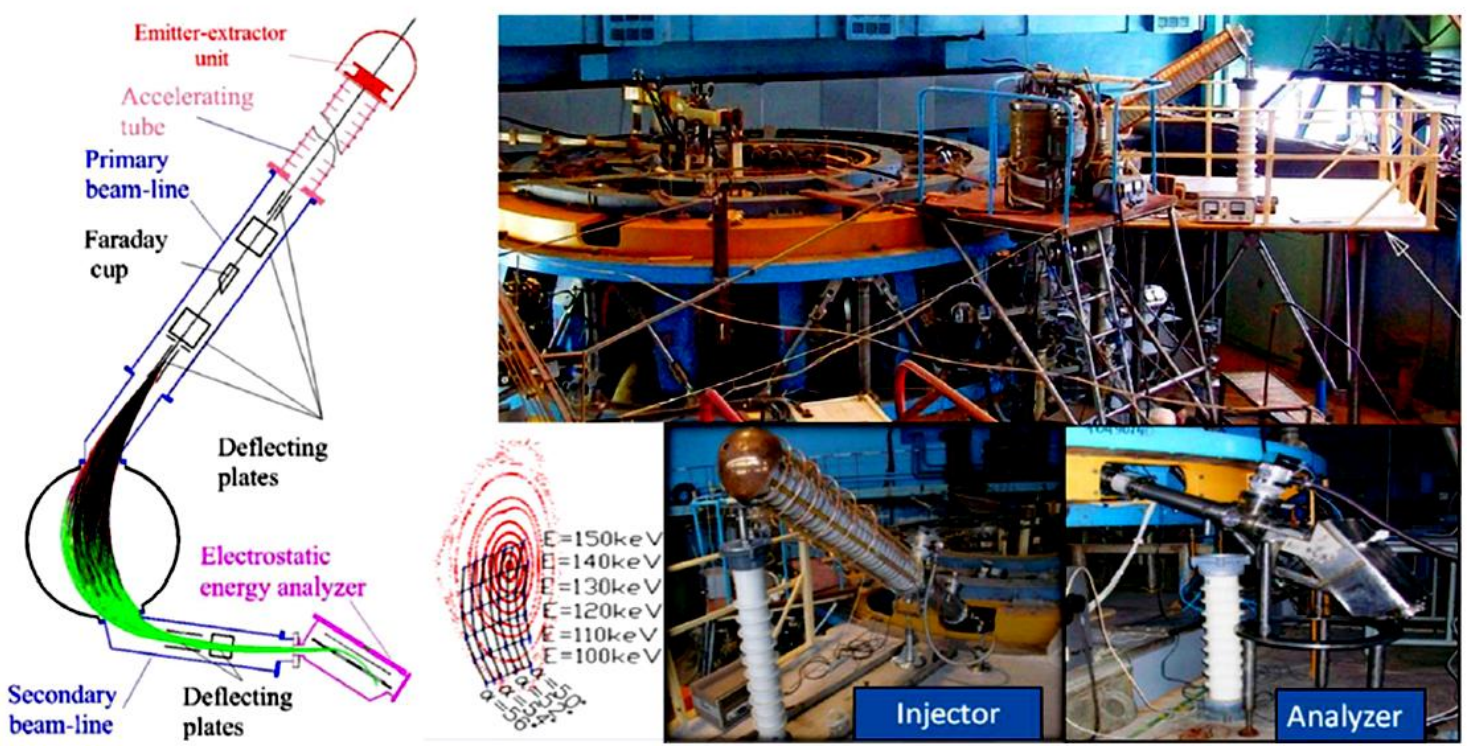

Fig. 9. HIBP diagnostics in the "Uragan-2M" stellarator

The newest control and data acquisition system was developed in KIPT on the basis of experience of HIBP operation in various machines. It allows us to exploit HIBP injector with fine-focused high-intensity beam $(50 \ldots 300 \mu \mathrm{A})$ without changing the ion emitter and hardware during a long time [90-92]. The first experiments were conducted with magnetic field $B_{\mathrm{t}}=0.39 \mathrm{~T}$ by $\mathrm{Cs}^{+}$ion beam with energy $E_{b}=70 \mathrm{keV}$ and intensity $55 \ldots 65 \mu \mathrm{A}$. The estimates of the plasma potential and density were done.

Evaluation of the plasma potential on "Uragan-2M" gives the core negative value $\varphi=-80 \mathrm{~V}$, which is consistent with the floating potential data by Langmuir probe.

Negative potential of low-density plasma in "Uragan-2M" is opposite from the positive one on TJ-II with ECRH, but agrees with the negative potential on TJ-II NBI plasma with $n_{e}>10{ }^{19} \mathrm{~m}^{3}$. The secondary ion current $I_{\text {tot }}$ agrees with the average plasma density, measured by a radio interferometer, $\bar{n}_{e}=(1.25 \ldots 2.5) \cdot 10^{18} \mathrm{~m}^{-3}$. We did not observe the $I_{t o t}$ oscillations so far. Unfortunately, the parameters of "Uragan-2M" plasma are not yet comfortable for HIBP application.

Concluding the saga about plasma diagnostics by the heavy ion beam, it should be emphasized once again that HIBP is still a very rare diagnostics. An individual design and development of HIBP hardware is required, starting from the calculation of the probing beam trajectories to select an optimized hardware arrangement, then creation of individual set of equipment, including both hardware and software for each fusion device.

\section{CONCLUSIONS}

After 50 years of development, HIBP has become a powerful multifunctional tool for magnetic fusion research. It makes a significant contribution to the study of the role of electric fields and plasma rotation in the energy and particle transport, plasma turbulence, $\mathrm{ZF}$ and
GAM, physics of fast particles and AEs. HIBP has become one of the most advanced diagnostics of the world level due to the expansion of its technical capabilities in Ukraine.

\section{ACKNOWLEDGEMENTS}

Finally, let me pay tribute to all colleagues from KIPT for their great work and significant contribution to development of active corpuscular diagnostics and its using in experiments with hot plasmas during a 50-years period. They are N.G. Shulika, P.A. Demchenko, I.S. Bondarenko, A.A. Chmyga, G.N. Deshko, N.B. Dreval, S.M. Khrebtov, A.D. Komarov, A.S. Kozachek, I.S. Nedzelskiy, Yu.Ya. Podopa, N.V. Samokhvalov, Yu.I. Tashchev, and A.I. Zhezhera. I am also grateful to our "comrades", first of all from Kurchatov Institute in Moscow, as well as Ioffe Institute in St. Petersburg and CIEMAT in Madrid. They are A.V. Melnikov,
L.G. Eliseev,
V.A. Mavrin,
S.E. Lysenko,
K.G. Shakhovets,
S.V. Lebedev,

L.G. Askinazi, J.L. de Pablos, et al. Special words of thanks, respect and appreciation go to Carlos Hidalgo, V.I. Tereshin, and K.A. Razumova. Owing to their scientific erudition, they appreciated and supported our activities. Without their decisive and persistent support HIBP diagnostics would not have been ever installed in any fusion facility.

This work has been supported in part by National Academy Science of Ukraine target program on Plasma physics.

\section{REFERENCES}

1. L.I. Krupnik, N.G. Shulika. Plasma diagnostics. M.: "Gosatomizdat", 1963, p. 199.

2. A.I. Kislyakov, L.I. Krupnik // Soviet Journal of Plasma Physics. 1981, v. 7, № 4, p. 866.

3. L.I. Krupnik, V.I. Tereshin // Plasma Physics Reports. 1994, v. 20, № 2, p. 157.

4. Yu.N. Dnestrovskii et al. // Soviet Journal of Plasma Physics. 1986, v. 12, p. 130. 
5. Ph.O. Khabanov et al. // Journal of Instrumentation. 2019, v. 14, p. C09033.

6. H. Weisen et al. // Fusion Science and Technology. 2011, v. 59, p. 418-426.

7. F. Wagner. // Plasma Physics and Controlled Fusion. 2007, v. 49, p. B1.

8. K. Itoh, S.-I. Itoh. // Plasma Physics and Controlled Fusion. 2007, v. 38, p. 1.

9. I. S. Bondarenko et al. // Soviet Journal of Technical Physics. 1986, v. 31, p. 1390.

10. V.I. Bugarya et al. // JETP Letters. 1983, v. 38, p. 404-408.

11. I.S. Bondarenko et al. // Soviet Journal of Plasma Physics. 1992, v. 18, p. 110.

12. A.V. Melnikov et al. HIBP diagnostics on T-10 // Review of Scientific Instruments. 1995, v. 66, p. 17.

13. A.V. Melnikov et al. // Fusion Engineering and Design. 2019, v. 146, Part A, p. 850-853.

14. L.G. Askinazi et al. // Technical Physics Letters. 2012, v. 38, p. 268.

15. I.S. Bondarenko et al. // Review of Scientific Instruments. 1997, v. 68, p. 12.

16. L.I. Krupnik et al. // Fusion Engineering and Design. 1997, v. 34-35, p. 639-644.

17. L.I. Krupnik et al. // Fusion Engineering and Design. 2001, v. 56-57, p. 935-939.

18. L.I. Krupnik et al. // Problems of Atomic Science and Technology. Series «Plasma Physics» (10). 2005, № 1, p. 215-217.

19. I.S. Bondarenko et al. // Problems of Atomic Science and Technology. Series «Plasma Physics» (15). 2009, № 1, p. 28-30.

20. Y. Podoba et al. // AIP Conference Proceeding. 2008, v. 993, p. 235.

21. L.I. Krupnik et al. // Fusion Science and Technology. 2006, v. 50, p. 276-280.

22. L.I. Krupnik et al. // Plasma Physics Reports. 1994, v. 20, p. 170-175.

23. A.V. Melnikov et al. // Fusion Technology. 1996, p. 889-892 (New York: "Elsevier", 1997).

24. A.V. Melnikov, L.G. Eliseev // Review of Scientific Instruments. 1999, v. 70, p. 951.

25. M.R. Siegrist et al. // Twenty-First IEEE/NPS Symposium on Fusion Engineering. 2005, p. 1-4.

26. A.A. Chmyga et al. // Problems of Atomic Science and Technology. Series «Plasma Physics» (9). 2003, № 1, p. 160-162.

27. S. Perfilov et al. // AIP Conference Proceeding. 2006, v. 812, p. 199.

28. S. Perfilov et al. // Fusion Science and Technology. 2007, v. 51, p. 38-45.

29. A.V. Melnikov et al. // Review of Scientific Instruments. 1997, v. 68, p. 316.

30. A.V. Melnikov et al. // 37-th EPS Conference on Plasma Physics. 2010 (Dublin, Ireland, 21-25 June 2010) ECA, v. 34A, P5.120.

31. P.O. Khabanov et al. // Problems of Atomic Science and Technology. Series «Plasma Physics» (26). 2020, № 6(130), p. 195-199.

32. A.V. Melnikov et al. // Fusion Engineering and Design. 2015, v. 96, 97, p. 306-310.

33. Yu.N. Dnestrovskij et al. // IEEE Transactions on Plasma Science. 1994, v. 22, p. 310.
34. A.V. Melnikov et al. // Nuclear Fusion. 2017, v. 57, p. 072004.

35. A.V. Melnikov. // Nature Physics. 2016, v. 12, p. 386-390.

36. A.V. Melnikov. M.: MEPhI, 2015, ISBN 978-57262-2165-6.

37. A.V. Melnikov. Springer Nature Switzerland AG, 2019, 240 p, ISBN 978-00-0480-1.

38. A.V. Melnikov et al. // Fusion Engineering and Design. 2015, v. 96-97, p. 724.

39. I.S. Bondarenko et al. // Review of Scientific Instruments. 2004, v. 75, p. 1835.

40. L.I. Krupnik et al. // IEEE Transactions on Plasma Science. 2008, v. 36, p. 1536-1544.

41. A.V. Melnikov et al. // Review of Scientific Instruments. 1997, v. 68, p. 308.

42. I. Bondarenko et al. // AIP Conference Proceeding. 2008, v. 993, p. 239.

43. A.M. Ilin, et al. // Journal of Physics: Conference Series. 2019, v. 1383, p. 012006.

44. L. Eliseev et al. // Plasma Fusion Research. 2012, v. 7, p. 2402064.

45. A.V. Melnikov et al. // Problems of Atomic Science and Technology, Series "Plasma Physics» (16). 2010, № 6(70), p. 40-42.

46. L.G. Eliseev et al. // Problems of Atomic Science and Technology. Series «Plasma Physics» (23). 2017, № 1(107), p. 241-243.

47. L.G. Eliseev et al. // Plasma Fusion Research. 2018, v. 13 , p. 3402106

48. C. Hidalgo et al. // Plasma Physics and Controlled Fusion. 2006, v. 48, p. S169-S176.

49. G. Van Oost et al. // Problems of Atomic Science and Technology. Series «Plasma Physics» (15). 2009, № 1(59), p. 8-12.

50. G. Van Oost et al. // Plasma Physics and Controlled Fusion. 2007, v. 49, p. A29-A44

51. V.I. Bugarya et al. // Nuclear Fusion. 1985, v. 25, p. 1707-1717.

52. M.A. Drabinskii et al. // Journal of Physics: Conference Series. 2016, v. 747, p. 012017.

53. I.S. Bondarenko et al. // Czechoslovak Journal of Physics. 2000, v. 50, p. 1397-1412.

54. I.S. Bondarenko et al. // Review of Scientific Instruments. 2001, v. 72, p. 583.

55. A. Chmyga et al. // 29-th EPS Conference on Plasma Physics and Controlled Fusion. 2002 (Montreux, 17-21 June 2002), ECA, v. 26B, O1.09.

56. L.I. Krupnik et al. // 30-th EPS Conference on Plasma Physics and Controlled Fusion. 2003 (St. Petersburg, 7-11 July 2003), ECA, v. 27A, P-1.24.

57. L.I. Krupnik et al. // 31-st EPS Conference on Plasma Physics. 2004 (London, 28 June - 2 July 2004), ECA, v. 28G, P-4.181.

58. E. Ascasibar et al. // Plasma Physics and Controlled Fusion. 2002 v. 44, No 12B B307-B322.

59. T Estrada et al. // Plasma Physics and Controlled Fusion. 2005, v. 47, p. L57.

60. L.I. Krupnik et al. // Czechoslovak Journal of Physics. 2005, v. 55, p. 317-340.

61.I.S. Bondarenko et al. // Czechoslovak Journal of Physics. 2000, v. 50, № 12, p. 1397-1412. 
62. A.V. Melnikov et al. // Problems of Atomic Science and Technology. Series "Thermonuclear Fusion». 2011, № 3, p. 54-73.

63. L.I. Krupnik et al. // Problems of Atomic Science and Technology. Series «Plasma Physics» (12). 2006, № 6, p. 37-40.

64. L.I. Krupnik et al. // AIP Conference Proceeding. 2006, v. 875, p. 99.

65. A.V. Melnikov et al. // Plasma Physics and Controlled Fusion. 2018, v. 60, 084008.

66. A.V. Melnikov et al. // Nuclear Fusion. 2011, v. 51, p. 083043.

67. A.V. Melnikov et al. // Plasma Physics and Controlled Fusion. 2018, v. 60, p. 084008.

68. A.V. Melnikov et al. // Fusion Science and Technology. 2004, v. 46, p. 299-307.

69. C. Hidalgo et al. // Plasma Physics and Controlled Fusion. 2004, v. 46, p. 287.

70. A. Fujisawa et al. // Nuclear Fusion. 2007, v. 47, p. S718-S726.

71. M. Garcia-Munoz et al. // Plasma Physics and Controlled Fusion. 2019, v. 61, p. 054007.

72. S. Yamamoto, et al. // Nuclear Fusion. 2020, v.70, p. 066018.

73. A.V. Melnikov et al. // Plasma Physics and Controlled Fusion. 2006, v. 48, p. S87-S110.

74. A.V. Melnikov et al. // Nuclear Fusion. 2015, v. 55, p. 063001 .

75. A.V. Melnikov et al. // Nuclear Fusion. 2017, v. 57, p. 115001 .

76. A.V. Melnikov et al. // Nuclear Fusion. 2010, v. 50, p. 084023.

77. A.V. Melnikov et al. // Nuclear Fusion. 2012, v. 52, p. 123004.

78. A.V. Melnikov et al. // Nuclear Fusion. 2016, v. 56, p. 076001.
79. A.V. Melnikov et al. // Nuclear Fusion. 2016, v. 56, p. 112019.

80. A.V. Melnikov et al. // Nuclear Fusion. 2018, v. 58, p. 0820191.

81. A.V. Melnikov et al. // Plasma and Fusion Research. 2011, v. 6, p. 2402030.

82. B.Ph. van Milligen et al. // Nuclear Fusion. 2011, v. 51, p. 013005.

83. L.I. Krupnik et al. / AIP Conference Proceeding. 2006, v. 875 , p. 95 .

84. L.I. Krupnik et al. // Problems of Atomic Science and Technology. Series «Plasma Physics» (15). 2009, № 1(59), p. 31-33.

85. L.I. Krupnik et al. // 33-rd EPS Conference on Plasma Physics. 2006 (Rome, 19-23 June 2006), ECA, v. 30I, P-1.138.

86. P.O. Khabanov et al. // Problems of Atomic Science and Technology. Series «Plasma Physics» (24). 2018, № 6 (118), p. 317-320.

87. A.I. Zhezhera et al. // Problems of Atomic Science and Technology. Series «Plasma Physics» (23). 2017, № 1 (107), p. 261-264.

88. F. Castejón et al. //Nuclear Fusion. 2017, v. 57, p. 102022.

89. J.A. Alonso et al. // Physical Review Letters. 2017, v. 118, p. 185002 .

90. A.D. Komarov et al. // Problems of Atomic Science and Technology. Series «Plasma Physics» (22). 2016, № 6(106), p. 306-309.

91. A.I. Zhezhera et al. // Problems of Atomic Science and Technology. Series «Plasma Physics» (21). 2015, № 1(95), p. 276-279.

92. L.I. Krupnik et al. // Problems of Atomic Science and Technology. Series «Plasma Physics» (26). 2020, v. 130, № 6, p. 190-194.

Article received 15.01.2021

\section{5О ЛЕТ ДИАГНОСТИКИ ГОРЯЧЕЙ ПЛАЗМЫ ЗОНДИРОВАНИЕМ ПУЧКОМ ТЯЖЕЛЫХ ИОНОВ В ХАРЬКОВСКОМ ФИЗИКО-ТЕХНИЧЕСКОМ ИНСТИТУТЕ}

\section{Л.И. Крупник}

Представлен обзор развития диагностики зондирования плазмы пучком тяжелых ионов (ЗППТИ) от истоков до сегодняшнего дня. Прогресс в пучковой технологии представлен на примерах ЗППТИ в токамаках и стеллараторах. Вначале методом ЗППТИ измерялся усредненный по времени потенциал плазмы в одной точке, затем он позволил находить радиальные распределения с временным разрешением, и, наконец, он становится многоцелевой диагностикой для изучения временной эволюции двумерных распределений потенциала и турбулентности, включая дальнодействующие корреляции потенциала, измеряемые сдвоенным ЗППТИ. Подробно рассмотрены эволюция профиля потенциала плазмы, связи между потенциалом, плотностью и удержанием, геодезические акустические моды, стационарные и чирпированные альфвеновские собственные моды, турбулентный поток частиц.

\section{0 РОКІВ ДІАГНОСТИКИ ЗОНДУВАННЯ ГАРЯЧОЇ ПЛАЗМИ ПУЧКОМ ВАЖКИХ ІОНІВ У ХАРКІВСЬКОМУ ФІЗИКО-ТЕХНІЧНОМУ ІНСТИТУТІ}

\section{Л.І. Крупнік}

Представлено огляд розвитку діагностики зондування плазми пучком важких іонів (ЗППВІ) від витоків до сьогодення. Прогрес у пучковій технології представлений на прикладах ЗППВІ в токамаках і стелараторах. Спочатку методом ЗППВІ вимірювала усереднені за часом потенціал плазми в одній точці, потім він дозволив знаходити радіальні розподіли з часовою роздільною здатністю, i, нарешті, він стає багатоцільовою діагностикою для вивчення часової еволюції двовимірних розподілів потенціалу і турбулентності, включаючи далекодіючі кореляції потенціалу, вимірювані здвоєним ЗППВІ. Детально розглянуто еволюцію профілю потенціалу плазми, зв'язку між потенціалом, густиною і утриманням, геодезичні акустичні моди, стаціонарні і чирпіровані альфвенівські власні моди, турбулентний потік частинок. 